4 J. P. Bernal ${ }^{1 *}$, Francisco W. Cruz ${ }^{2}$, Nicolás, M. Stríkis ${ }^{2,3}$, Xianfeng Wang ${ }^{4}$, Michael Deininger ${ }^{5}$, 5 Maria Carolina A. Catunda ${ }^{2}$, C. Ortega-Obregón ${ }^{1}$, Hai Cheng $^{6,7}$, R. Lawrence Edwards ${ }^{7}$, 6 Augusto S. Auler ${ }^{8}$

\section{High-resolution Holocene South American monsoon history recorded by a speleothem from Botuverá Cave, Brazil}

1) Centro de Geociencias, Universidad Nacional Autónoma de México. Campus UNAM Juriquilla, Querétaro, México 76230

2) Instituto de Geociências, Universidade de São Paulo, Rua do Lago 562, Sao Paolo, Brasil

3) Departamento de Geoquímica, Universidade Federal Fluminense, Rua Outeiro de São João Batista, s/n, Niterói, Brasil.

4) Earth Observatory of Singapore, Nanyang Technological University, Singapore

5) School of Geological Sciences, University College Dublin, Belfield, Dublin 4, Ireland

6) Institute of Global Environmental Change, Xi'an Jiaotong University, Xi'an, China

7) Department of Geology and Geophysics, University of Minnesota, Minneapolis, Minnesota 55455, USA

8) Instituto do Carste, Rua Brasópolis, 139, Floresta, Belo Horizonte/MG, Brasil
9

\section{0}

1

22 23

${ }^{*}$ Corresponding author: jpbernal@unam.mx 


\section{High-resolution Holocene South American monsoon history recorded by a speleothem from Botuverá Cave, Brazil (Bernal et al).}

25

26

27 Abstract

28 A Holocene stalagmite from Botuverá Cave, southeastern Brazil was analyzed by LA-ICPMS

29 for $\mathrm{Mg} / \mathrm{Ca}, \mathrm{Sr} / \mathrm{Ca}, \mathrm{Ba} / \mathrm{Ca}$. The observed variability in the record was demonstrated to be 30

31 We find that the calcite $\delta^{18} \mathrm{O}$ is strongly correlated with $\mathrm{Sr} / \mathrm{Ca}$, indicating that atmospheric

32 circulation over South America and monsoon intensity have been tightly correlated throughout

33

34

35

36

37

38

39

40

41

42

43

44

45

46

47 most of the Holocene, both directly responding to solar precession. Comparison with other

contemporaneous high-resolution hydroclimate records reveals that SAMS has shown a degree

of complexity during the Holocene not previously detected, with periods where the South

American Convergence Zone (SACZ) expanded to cover most of the South American sub-

continent, and coincident with periods of low-SST in the north Atlantic. We also detect

periods where rainfall amount in northeastern and southeastern Brazil are markedly anti-

phased, suggesting a north-south migration of SACZ, which it appears to be mediated by solar irradiance. The high-resolution nature of our record allow us to examine the effect that

Holocene climate anomalies had upon SAMS dynamics and hydroclimate in southeastern

Brazil, in particular the $8.2 \mathrm{ka}$ event and the Little Ice Age. In addition to confirm the internal structure of the events, we also detect the possible consequences of the climatic anomalies upon ocean-atmosphere interactions through its effects upon SAMS. 


\section{High-resolution Holocene South American monsoon history recorded by a speleothem from Botuverá Cave, Brazil (Bernal et al).}

1. Introduction:

The South American Monsoon System (SAMS) refers to the austral summer season features of deep convective activity and large scale circulation over South America (Liebmann and Mechoso, 2011) from which one of most important biodiversity hotspot in the tropics, the Atlantic Rainforest, has relied upon during late Quaternary (Carnaval et al., 2009), and it is the main source of rainfall for the most densely-populated areas of South America. Because of its importance, an increasing number of studies have focused on deciphering the natural variability of SAMS on orbital to millennial time-scales and have established links to Northern Hemisphere climate (e.g. Cruz et al., 2005a; Cruz et al., 2009; Stríkis et al., 2011; Wang et al., 2006). More recently, high-resolution paleoclimate records from South America have been able to reveal the modulation/coupling of SAMS by different (multi)decadal climatic modes, and/or solar oscillations (Apaéstegui et al., 2014a; Bird et al., 2011; Chiessi et al., 2009; Novello et al., 2012; Thompson et al., 2013; Vuille et al., 2012). Most of these reconstructions are focused on the last two millennia, and only Chiessi et al., (2009) covers a period of $\sim 4.5 \mathrm{ka}$ during the last glacial maximum; yet, there is still no reconstruction of SAMS in subtropical South America providing evidence for hydroclimate modulation by multi-decadal climatic modes during the entire Holocene period when climate changed substantially from low to high phases of austral summer insolation. In this regard, it is necessary to obtain long, well-dated and highly resolved records of past SAMS's activity in an attempt to discuss the possible modulation of precession forcing on the high frequency precipitation variability. Such records also have the potential to provide valuable information on the coupling/decoupling of monsoonal systems with the different climatic modes, and/or reveal the possible influence from solar activity on climate instability or abrupt climate changes, providing a unique insight into the high-resolution paleoclimate dynamics during such events. 


\section{High-resolution Holocene South American monsoon history recorded by a speleothem from Botuverá Cave, Brazil (Bernal et al).}

Oxygen-isotope records from stalagmites have provided many robust paleoclimate reconstructions spanning several thousands of years because variability in the carbonate $\delta^{18} \mathrm{O}$ can be interpreted to reflect changes in the isotopic composition of local rainfall, which can be a function of moisture source, rainfall amount, or atmospheric equilibrium temperature (Lachniet, 2009). However, obtaining $\delta^{18} \mathrm{O}$ records with high temporal resolution is complex and labor intensive (e.g. Treble et al., 2007), and is usually limited to samples with relatively high growth rates (> $50 \mu \mathrm{m} /$ year), hampering our general understanding on how highfrequency climate modes and solar oscillations might have potentially impacted the different monsoonal systems in the world. This has led to the development of alternative rainfall proxies in stalagmites, among which, trace element variability is probably the most promising (Fairchild and Treble, 2009).

Trace element variability in stalagmites has been studied for several years (Fairchild and Treble, 2009), but the complexity and variety of geochemical processes to which they can be subjected in the epikarst hampers the establishment of a general model to explain trace element variations. Yet, the increasing knowledge on the geochemical processes modulating the abundance of some trace elements in the epikarst, as well as their incorporation into the speleothem calcite (Sinclair, 2011; Stoll et al., 2012; e.g. Treble et al., 2005; Tremaine and Froelich, 2013), along with the development and availability of different microbeam techniques, have permitted the construction of records with high spatial- and chronological resolution using laser ablation-ICPMS (Treble et al., 2003), secondary ionization massspectrometry (Smith et al., 2009) and micro-XRF (e.g. Borsato et al., 2007); thus allowing the construction of records with high-temporal resolution even from slow-growing stalagmites, which can complement complex $\delta^{18} \mathrm{O}$ records. 


\section{High-resolution Holocene South American monsoon history recorded by a speleothem from Botuverá Cave, Brazil (Bernal et al).}

Long trace element records can also provide additional information for the interpretation of speleothem $\delta^{18} \mathrm{O}$ records where the isotopic composition of local

precipitation and seepage, which is finally recorded by speleothems, can be modulated by more than one fractionation process (e.g. source and rainfall amount). This is the case of southern Brazil, where two isotopically distinct moisture sources, Amazonian and extratropical, dominate rainfall regimes during the summer and winter, respectively (Cruz et al., 2005b).

Consequently, speleothem $\delta^{18} \mathrm{O}$ cannot be used as a proxy of mean rainfall accumulation because the amount effect is not evident and is poorly correlated with $\delta^{18} \mathrm{O}$ in the region (Cruz et al, 2005, Vuille and Werner, 2005). If, however, the variability on the abundance of trace elements is demonstrated to be modulated by karst humidity and prior calcite precipitation, such as in caves from Southeastern Brazil (Karmann et al., 2007), then it is possible to build a more complete and precise hydroclimate reconstruction. Indeed, by examining the variability of both, trace element and $\delta^{18} \mathrm{O}$ records, it can be possible to obtain information on changes in moisture sources and amount with high temporal resolution, providing a more detailed description of the climatic patterns and atmosphere dynamics modulating hydroclimate in the area.

Here, we present a high-resolution trace element record in a stalagmite from Botuverá Cave (southeastern Brazil) spanning most of the Holocene using LA-ICP-MS providing the most detailed record of Holocene hydroclimate yet available for this area. Paleoclimate records from this cave are, arguably, among the most robust climate reconstructions for South America (Cruz et al., 2006a; Cruz et al., 2005b; Wang et al., 2006; Wang et al., 2007), but due to the slow growth rate exhibited by the collected stalagmites $(2-10 \mu \mathrm{m} /$ year $)$, construction of records of hydroclimate variability based on calcite $\delta^{18} \mathrm{O}$ with high temporal-resolution is difficult. We present evidence supporting that the observed variability in trace elements is 


\section{High-resolution Holocene South American monsoon history recorded by a speleothem from Botuverá Cave, Brazil (Bernal et al).}

119

120

121

122

123

124

125

126

127

128

129

130

131

132

133

134

135

136

137

138

139

140

mostly modulated by changes in the karst humidity, thus rainfall amount. This allows us to identify the diverse set of climatic modes (e.g. AMO) and forcing mechanisms (e.g. solar

variability) that have been modulating the strength of the South American Monsoon System, and determine that SAMS evolution throughout the Holocene has been the result from a complex interplay by different forcing mechanisms.

2. Samples and Methods

Botuverá cave (Figure 1, $27^{\circ} 13^{\prime} \mathrm{S}$; 49 09’ W, $230 \mathrm{~m}$ above sea level) is located in Santa Catarina State, Southern Brazil, and is hosted within carbonates and sediments from the Brusque Group (Auler, 2002), a succession of metavolcanosedimentary rocks from the Neoproterozoic with an age of c.a. $600 \mathrm{Ma}$ (Basei et al., 2011). Sample BTV21a is a $22.5 \mathrm{~cm}$ long stalagmite collected in 2002. Visual inspection of the sample reveals that there are no evident changes in growth direction or long hiatuses, an observation supported also on the resulting age-model (Figure 2). Modern climatic conditions in the area have been described elsewhere (Cruz et al., 2007a). The stalagmite was sectioned and a linear age-model was developed from $13 \mathrm{U} / \mathrm{Th}$ ages measured at the Minnesota Isotope Laboratory, University of Minnesota, and at the Earth Observatory of Singapore, using the methods described in (Shen et al., 2002).

Oxygen and carbon stable isotope analyses were carried out at the University of Minnesota following the procedures and quality control described in (Wang et al., 2006). Trace element ratios were obtained by Laser-ablation ICP-MS using a Resonetics L-50 excimer laserablation workstation (ArF, $\lambda=193 \mathrm{~ns}, 23 \mathrm{~ns}$ FWHM, fluence of $\sim 6 \mathrm{~J} / \mathrm{cm}^{2}$ ) at Centro de 


\section{High-resolution Holocene South American monsoon history recorded by a speleothem from Botuverá Cave, Brazil (Bernal et al).}

141 Geociencias, Universidad Nacional Autónoma de México (UNAM). Details on the analytical

142 protocols used here are described in the supplemental material.

144 Redfit module (Schulz and Mudelsee, 2002) as incorporated in PAST v 3.03 (Hammer et al.,

145 2001). Wavelet analysis was performed using a Morlet wavefunction using the protocols

146 developed by Grinsted et al., (2004) for Matlab®.

3. Results

stalagmite has a typical crustal ${ }^{230} \mathrm{Th} /{ }^{232} \mathrm{Th}=(4.4 \pm 2.2) \times 10^{-6}$ and $\left({ }^{232} \mathrm{Th} /{ }^{238} \mathrm{U}\right)=1.2 \pm 0.5$

154 (McDonough and Sun, 1995) and, essentially, in secular equilibrium; i.e. $\left({ }^{230} \mathrm{Th} /{ }^{238} \mathrm{U}\right.$ ) and

\footnotetext{
${ }^{1}$ Round brackets denote activity ratios calculated using the decay constants from Cheng, et-al (2000). We note that using the more recent values reported by Cheng et al (2013) does not yield significantly different activity ratios, ages or uncertainties
} 


\section{High-resolution Holocene South American monsoon history recorded by a speleothem from Botuverá Cave, Brazil (Bernal et al).}

161 year between 7000 and 8000 y B.P. and 1300 to 300 y B.P., respectively (Figure 2B). The

162 robustness of the chronology and the age model presented here is supported by the close

163 agreement between our record and other independently-dated records from other localities.

164 Figure 2C also shows a gradual decrease in $\delta^{234}$ Uo throughout the period of stalagmite growth, 165 from $\delta^{234} \mathrm{Uo} \sim 3200 \%$ during the early Holocene to $2680 \%$ in the late Holocene. The

166 hydrological implications of such shift are discussed below.

171 Holocene to more negative, or lower, $\delta^{18} \mathrm{O}$ values during the late Holocene (Supplemental

172 material Figure SP2), which has been interpreted to reflect increased intensity of SAMS (Cruz

173 et al., 2005a). We note that the $\delta^{18} \mathrm{O}$ variability in BTV21a nicely replicates other

174 contemporaneous stalagmites from Botuverá Cave (Cruz et al., 2005a; Wang et al., 2006; Wang

175 et al., 2007), providing strong evidence for calcite precipitation in isotopic equilibrium

176 (supplemental material figure SP2). This is further supported by the absence of any correlation

177 between $\delta^{18} \mathrm{O}$ and $\delta^{13} \mathrm{C}\left(\mathrm{R}^{2}=0.0303\right)$, which would be expected under isotope kinetic effects

178 (Hendy, 1971). Therefore, kinetic fractionation during calcite precipitation is not a dominant

179 process affecting the $\delta^{18} \mathrm{O}$ and $\delta^{13} \mathrm{C}$ variability in BTV21a. 


\section{High-resolution Holocene South American monsoon history recorded by a speleothem from Botuverá Cave, Brazil (Bernal et al).}

3.3. Geochemical controls on stalagmite $\mathrm{Mg} / \mathrm{Ca}$, $\mathrm{Sr} / \mathrm{Ca}$ and $\mathrm{Ba} / \mathrm{Ca}$

The $\mathrm{Mg} / \mathrm{Ca}, \mathrm{Sr} / \mathrm{Ca}$ and $\mathrm{Ba} / \mathrm{Ca}$ records in BTV21a are composed of nearly fiftythousand independent points, resulting in a time-series of sub-annual resolution, with an average of five points per year throughout the Holocene. The large variability in the record was reduced by calculating a 200-point running mean using a rectangular window. The "smoothed" time-series are used throughout this work. Despite the high-resolution of the record, no annual cycles were detected in both non-smoothed and smoothed data.

Figure 3 shows the trace element record for BTV21a. $\mathrm{Mg} / \mathrm{Ca}$ and $\mathrm{Sr} / \mathrm{Ca}$ ratios range from 222 to $333 \mathrm{mmol} / \mathrm{mol}$ and 60 to $30 \mathrm{mmol} / \mathrm{mol}$, respectively, whilst $\mathrm{Ba} / \mathrm{Ca}$ ratios vary between 0.5 and $1.1 \mathrm{mmol} / \mathrm{mol}$. In general, the trace element ratios co-vary throughout the Holocene, with exception of the last millennia where two significant and abrupt excursions to high $\mathrm{Mg} / \mathrm{Ca}$ ratios are observed. A gradual decrease in $\mathrm{Mg} / \mathrm{Ca}, \mathrm{Sr} / \mathrm{Ca}$ and $\mathrm{Ba} / \mathrm{Ca}$ is observed from 7300 y B.P. onwards.

Several geochemical processes can modulate the relative abundance of trace elements in the stalagmite, such as prior calcite precipitation (PCP), incongruent calcite dissolution (ICD) as well as mixing between two or more sources. From these, only PCP can be linked with external atmospheric conditions, as a lower vadose zone aquifer above the cave favors the precipitation of calcite upstream the stalagmite, as fissure and secondary conduits are ventilated during dry periods, allowing $\mathrm{CO}_{2}$ degasification, thus favoring calcite precipitation and leading to the enrichment of incompatible trace elements, such as $\mathrm{Mg}$, $\mathrm{Sr}$ and $\mathrm{Ba}$, relative to $\mathrm{Ca}$ in the seepage water, hence, the stalagmite (Fairchild et al., 2000). Conversely, during wet periods, precipitation of calcite upstream the seepage flow pathway is less likely to occur since the karstic porosity where $\mathrm{CO}_{2}$ degasification takes place are likely to be filled with water, resulting 


\section{High-resolution Holocene South American monsoon history recorded by a speleothem from Botuverá Cave, Brazil (Bernal et al).}

205 in little or no significant change in the relative concentration of trace elements. Consequently, 206 it is essential to identify which, of any of these processes, is more significant in modulating the 207 observed variability in $\mathrm{Mg} / \mathrm{Ca}, \mathrm{Sr} / \mathrm{Ca}$ and $\mathrm{Ba} / \mathrm{Ca}$.

208

209

210

211

212

213

214

215

216

217

Sinclair (2011) has demonstrated that if PCP modulates Mg/Ca and Sr/Ca variability, and in the absence of kinetic control, the molar ratios (mol Mg/mol $\mathrm{Ca}$ and $\mathrm{mol} \mathrm{Sr} / \mathrm{mol} \mathrm{Ca}$ ) should co-vary linearly in a ln-space, with a slope of $0.88 \pm 0.13$. Figure 4 a shows that $\ln (\mathrm{Mg} / \mathrm{Ca})$ and $\ln (\mathrm{Sr} / \mathrm{Ca})$ from BTV21a have a strong linear co-variation $(\mathrm{R}=0.51)$, but fail to represent the expected trend if PCP were the only process modulating their variability, as the resulting slope $(\mathrm{m}=0.55)$ indicates that other processes, have impinged upon the abundances of $\mathrm{Mg}$ and $\mathrm{Sr}$ in the stalagmite. This is probably the result from dissolution of high- $\mathrm{Mg}$ carbonates from the Brusque group (Basei et al., 2011) where the caves is hosted. In particular $\mathrm{Mg} / \mathrm{Ca}$ appears to be more affected as it shows large and abrupt variability during the last millennia, not observed in the Sr/Ca record, suggesting the presence of an additional source of $\mathrm{Mg}$ but not of Sr to the seepage waters in the karstic environment. This implies that while Mg variability might be affected by two or more geochemical processes in the epikarst, they might not have affected significantly the Sr/Ca variability in the Btv21a trace-element record.

To verify whether Sr/Ca was mostly modulated by PCP, we tested the thermodynamic and kinetic assumptions of Sinclair (2011), using the experimentally derived distribution coefficients for $\mathrm{Sr} / \mathrm{Ca}$ and $\mathrm{Ba} / \mathrm{Ca}$ at $25^{\circ} \mathrm{C}$ by Day and Henderson (2013). Accordingly, if PCP modulated their variability during stalagmite growth, then the observed molar ratios should covary linearly in the ln-space, with a slope of $1.02 \pm 0.08$. Figure $4 \mathrm{~B}$ shows that the $\mathrm{Sr} / \mathrm{Ca}$ and $\mathrm{Ba} / \mathrm{Ca}$ molar ratios measured in BTV21a closely follows the expected trend, suggesting that 


\section{High-resolution Holocene South American monsoon history recorded by a speleothem from Botuverá Cave, Brazil (Bernal et al).}

227 their variability is largely modulated by PCP and, consequently, reflecting changes in water 228 residence time in the epikarst.

229

230

231

232

233

234

235

236

237

238

239

240

241

242

243

244

245

246

247

Further evidence supporting the change in water residence time in the epikarst comes from the $\delta^{234}$ Uo measured in the stalagmite (Table SP1 and Figure 2C). High $\delta^{234}$ Uo values are usually interpreted to result from dry periods where water-rock interaction time is long, while lower $\delta^{234}$ Uo values can result from wet periods with short water residence time in the epikarst (e.g. Polyak et al., 2012). Under this light, the gradual decrease in $\delta^{234} U$ in BTV21a, from $\sim 3200 \%$ o during the early Holocene to $\sim 2680 \%$ in the late Holocene indicate a gradual change in the water residence time that is also consistent with the interpretation of the Sr/Ca record.

Figure 4C shows that $\mathrm{Sr} / \mathrm{Ca}$ and $\mathrm{Ba} / \mathrm{Ca}$ in BTV21a are also strongly correlated with calcite $\delta^{18} \mathrm{O}$, with $\mathrm{Sr} / \mathrm{Ca}-\delta^{18} \mathrm{O}$ correlation coefficient $\mathrm{R}=0.8794$ and $\mathrm{Ba} / \mathrm{Ca}-\delta^{18} \mathrm{O} \mathrm{R}=0.7726$.

Speleothem $\delta^{18} \mathrm{O}$ values from Botuverá Cave reflect rainfall $\delta^{18} \mathrm{O}$ values (Cruz et al., 2006b;

Cruz et al., 2005b; Wang et al., 2006; Wang et al., 2007), which is mainly modulated by the pathways that air masses follow before reaching Botuverá (Figure 1), with more negative $\delta^{18} \mathrm{O}$ values for Amazonian moisture during the active phase of the South American Monsoon $\left(\delta^{18} \mathrm{O}\right.$ $\sim 7.0 \%$ o), and rainfall associated with heavier moisture in ${ }^{18} \mathrm{O}$ from adjacent Atlantic Ocean when extratropical cyclones $\left(\delta^{18} \mathrm{O} \sim 3.0 \%\right.$ ), reach the coastal area of southern Brazil during the southern hemisphere winter (Cruz et al., 2005b). Combined, the trace element and $\delta^{18} \mathrm{O}$ records from BTV21a are a unique archive of SAMS dynamics and changes in mean rainfall in southeastern Brazil throughout most of the Holocene, thus the forthcoming discussions and interpretations will be based solely on the observed variability of $\mathrm{Sr} / \mathrm{Ca}$ and $\delta^{18} \mathrm{O}$. 


\section{High-resolution Holocene South American monsoon history recorded by a speleothem from Botuverá Cave, Brazil (Bernal et al).}

249

250

251

252

253

254

255

256

257

258

259

260

261

262

263

264

265

266

267

268

269

270

271

4. Discussion

4.1. Millenial scale hydroclimate variability in Botuverá

The combined $\delta^{18} \mathrm{O}$ and $\mathrm{Sr} / \mathrm{Ca}$ ratio records from BTV21a and its strong positive correlation (Figure 5A) suggests that most of the changes in total rainfall during the Holocene have been driven by SAMS intensity and, thus, it has been the dominant rainfall regime in southeastern Brazil during the last 9,000 years. Moreover, the combined record from BTV21a closely follows summer insolation at $30^{\circ} \mathrm{S}$ (Figure 5A), indicating that insolation has not only been the driver for changes in rainfall regimes (tropical vs extratropical) in southeastern Brazil (Cruz et al., 2005a), but also of rainfall amount during the Holocene. The gradual decrease in $\delta^{18} \mathrm{O}$ and $\mathrm{Sr} / \mathrm{Ca}$ and since $\sim 7000 \mathrm{ka}$ indicates an intensification of SAMS from early to late Holocene that resulted in higher mean regional rainfall amount, which reached its long-term optimum 4000 years ago, when summer insolation changed to its high-phase in the Southern Hemisphere (Figures 3 and 5). This feature is consistent with previous work by Cruz et al. (2007b), and is in accordance with Monsoon precipitation records from Amazon region after 4 ky that support the enhancement of moisture transport to southeastern Brazil from distal sources (Cheng et al., 2013b).

Our record indicates a suppressed monsoon intensity during the early Holocene, which is consistent with the lower sedimentation rates observed in La Plata Drainage Basin during this period (Razik et al., 2013). This implies that the mean annual rainfall contribution from Amazonian sources into southeastern Brazil was not as important during the early Holocene as it is today. The combined record also suggests that during the early Holocene, with a depressed SAMS (average calcite $\delta^{18} \mathrm{O}=-2.5 \pm 0.1 \%$ ), rainfall amount was highly variable but, on average, similar to that observed during the mid-Holocene (5000-6000 years), when the 


\section{High-resolution Holocene South American monsoon history recorded by a speleothem from Botuverá Cave, Brazil (Bernal et al).}

272 contribution from Amazonian moisture sources was more significant and resulted in slightly

273 lower average calcite $\delta^{18} \mathrm{O}(-3.0 \pm 0.2 \% 0)$. Furthermore, our data suggests that during the late

274 Holocene, the total amount of rainfall was higher when compared to the early and mid-

275 Holocene, though its variability was smaller. Such long-term enhancement of SAMS during the

276 Late Holocene is the response to higher austral summer insolation (Figure 5) and also to a

277 more southern location of the ITCZ during this period (Haug et al., 2001).

The Sr/Ca record from BTV21a shows a series of decadal to centennial-scale

279

280

281

282

283

284

285

286

287

288

289

290

291

292

293

294

excursions towards more humid conditions, some of which are also present in the $\delta^{18} \mathrm{O}$ record, suggesting that these represent an enhancement of monsoonal conditions in southeastern Brazil. Figure 5A compares the $\mathrm{Sr} / \mathrm{Ca}$ and $\delta^{18} \mathrm{O}$ records from Botuverá Cave with two highresolution records of monsoon variability from South America: Lapa Grande Cave (LG) located in central-eastern Brazil (Stríkis et al., 2011), and Huagapo Cave (HC) from central Andes in Peru (Kanner et al., 2013). The LG record is characterized by a series of large and abrupt excursions towards more negative $\delta^{18} \mathrm{O}$ which have been interpreted to be a consequence of cooling in the North Atlantic SST throughout the Holocene (Stríkis et al., 2011), due to the periodical increase in sea-ice and glacial ice circulating in the surface waters of the North Atlantic (Bond et al., 2001). Such events of abrupt monsoon intensification are also observed in the HC and the BTV21a records (Figure 5A), particularly, during the mid- and late-Holocene, when Amazonian moisture contributions into total rainfall at our site are more significant than in the early Holocene. The most intense of these events occurs at $\sim 5,000$ years B.P., as reflected by a $\sim 2 \%$ excursion in the $\delta^{18} \mathrm{O} L \mathrm{~L}$ record, and about 0.5 to $0.75 \%$ in the $\delta^{18} \mathrm{O} H \mathrm{HC}$ and BTV21a records, respectively, and has also been recently reported in the northeastern Peruvian Andes (Bustamante-Rosell et al., Accepted). We note that this event, in 


\section{High-resolution Holocene South American monsoon history recorded by a speleothem from Botuverá Cave, Brazil (Bernal et al).}

295 particular, corresponds to the most important change in SST in the north Atlantic during the

296 Holocene, as attested by the variability in \% of hematite stained glass in marine cores (Bond et

297 al., 2001).

298

299

300

301

302

303

304

305

306

307

308

309

310

The correspondence of wet events throughout most of South America indicates a widespread intensification of SAMS as a result from cool SST conditions in the North Atlantic. Similar relationships between precipitation amount in tropical America and North Atlantic SST have been previously reported to occur during the Holocene (Baker et al., 2005). However, the geographical extent of these wet periods is unprecedented for South America during the Holocene, and are likely to be the result from the expansion of the geographical extent of the South American Convergence Zone (SACZ), leading to an increase in rainfall amount in most of the South American sub-continent. We note that similar expansion of SACZ has been recently detected to occur during glacial times, also contemporaneous to low North Atlantic SST stadials (Stríkis et al., 2015). The periodic strengthening of SAMS observed here is probably the result from the adjustment of the ITCZ latitude forced by changes in SST in the North Atlantic, resulting in enhanced moisture transport towards western Amazon and, eventually, southeastern Brazil.

The comparison between BTV21a and HC and LG records reveal that monsoon strength in the western Amazon, southeastern and central Brazil have been directly correlated at different stages of the Holocene, however this has not always been the case. This is best exemplified during the $7-8$ ky period where BTV21a and LG records show a remarkable anticorrelation, $\mathrm{R}=-0.73$, (Figures $5 \mathrm{~B}$ ) that is not observed elsewhere in the record comparison. During this period, the Sr/Ca record in BTV21a shows two events when precipitation increased significantly, nearly reaching late-Holocene levels, and centered at 7.8 and $7.2 \mathrm{ky}$, 


\section{High-resolution Holocene South American monsoon history recorded by a speleothem from Botuverá Cave, Brazil (Bernal et al).}

318

319

320

321

322

323

324

325

326

327

328

329

330

331

332

333

334

335

336

337

338

339

340

respectively, (Figures $5 \mathrm{~A}-5 \mathrm{~B})$. These are accompanied by a slight decrease in $\delta^{18} \mathrm{O}(\sim 0.5 \% 0)$, indicating an increase in the proportion of Amazonian moisture reaching southeastern Brazil.

Such excursions are mirrored in the LG record by two contemporaneous shifts of up to $1 \% 0$ towards less negative $\delta^{18} \mathrm{O}$, indicating significant suppressions of the monsoon in central eastern Brazil (Figures 5A-5B). Such anti-phasing between both sites is likely to be the result from the multidecadal to centennial-scale oscillatory North-South migration of the SACZ leading to wet conditions in Botuverá, and diminished rainfall to the north at Lapa Grande cave site when SACZ shifts to the south. Figures 5B and 5C compares the BTV21a Sr/Ca record and the $\delta^{18} \mathrm{O}$ from LG with the excess of ${ }^{14} \mathrm{C}$ in corals and tree rings form INTCAL04 (Reimer et al., 2004) as a proxy of solar irradiance for the 7-8 ky period, and shows that rainfall amount in southeastern Brazil was tightly correlated with solar irradiance $(\mathrm{R}=0.57)$, but anticorrelated in Lapa Grande $(\mathrm{R}=-0.53)$. Such (anti)correlation between both records and the solar radiation indicates that the SACZ position, hence hydroclimate in southeastern and central Brazil, was non-linearly influenced by solar activity during this period, after which additional forcing factor(s) took over, essentially decoupling precipitation in both places.

\subsection{Spectral and wavelet analyses}

We performed spectral and wavelet analyses of the Sr/Ca record from BTV21a. To simplify the calculation requirements, an annually-resolved time series was generated by resampling from the high-resolution record; we note that de-trending of the dataset did not produce significantly different results as it only eliminated the modes with longer frequencies.

Figure 6A shows the Lomb-Scargle spectrum of the Sr/Ca record obtained using REDFIT (Schulz and Mudelsee, 2002), and it shows a series of signals above the $99 \% \chi^{2}$ red-noise level 


\section{High-resolution Holocene South American monsoon history recorded by a speleothem from Botuverá Cave, Brazil (Bernal et al).}

341 that attest to the complexity of SAMS and its various modes of oscillation during the

342 Holocene. Figure 6B shows the Morlet wavelet for modes of oscillation between 256 and 16

343 years, and shows that most of the signals above the red-noise level in the Lomb-Scargle

344 spectrum have been quasi-persistent throughout the Holocene, but none of them has been

345 fully persistent during the entire period of stalagmite growth.

346

347

348

349

350

351

352

353

354

355

356

357

358

359

360

361

362

363

The strongest signal above the $99 \% \chi^{2}$ red-noise level in the spectral analysis is

centered at 0.013 and $0.018 \mathrm{yr}^{-1}$ (75-55 years), which is identical to the pattern of oscillatory changes in SST in the North Atlantic (Schlesinger and Ramankutty, 1994), also stated as the Atlantic Multidecadal Oscillation (AMO). Because the AMO 60-year signal is the strongest in the spectrum, it would appear reasonable to assume that the AMO modulation upon SAMS has been persistent throughout the duration of our record ( $>9,000$ years); however, wavelet analysis of the record (Figure 6B) shows that the strength of AMO modulation of SAMS has been intermittent throughout the Holocene, with some short periods where very weak or no modulation is detected.

The sporadic strengthening and weakening of AMO modulation has also been observed in several locations in South America, (Apaéstegui et al., 2014a; Bird et al., 2011; Chiessi et al., 2009; Novello et al., 2012; Vuille et al., 2012) as well as in multiple proxies in the Atlantic Basin (Knudsen et al., 2011). Despite this, it is difficult to ascertain the specific role that AMO might have upon SAMS; this is because the periods where the power of the AMO signal is significant are not necessarily associated with strengthening or weakening of SAMS in southeastern Brazil or elsewhere. Moreover, SAMS-AMO coupling is not easily recognized in the re-analysis of modern climate datasets (Garreaud et al., 2009) hampering the use of modern climate dynamics to draw analogue paleoclimatic scenarios. 


\section{High-resolution Holocene South American monsoon history recorded by a speleothem from Botuverá Cave, Brazil (Bernal et al).}

364

365

366

367

368

369

370

371

372

373

374

375

376

377

378

379

The spectral analysis also reveals a series of signals above the $99 \% \chi^{2}$ red-noise level corresponding to $141,85,67,57$, and $45 \mathrm{y}$, which are identical to the periodicity observed for solar cycles detected on variations in atmospheric ${ }^{14} \mathrm{C}$ variability recorded in tree-rings (Stuiver and Braziunas, 1989). This indicates that, in addition to the millennial scale solar forcing that has been known to modulate SAMS for over 100ky (Cruz et al., 2005a; Wang et al., 2006), and which had an impact on modulating precipitation in Botuverá during the early Holocene (Figure 6), high-frequency centennial and decadal scale solar oscillations might have also modulated the intensity of the SAMS in southeastern Brazil. Wavelet analysis of the record (Figure 6B) shows that, similarly as the AMO, modulation by these high-frequency oscillations has not been persistent throughout the Holocene. In contrast, the wavelet analysis also reveals two signals at approximately 420 and 210 years, those have been persistent throughout the record and were not above the $99 \% \chi^{2}$ red-noise level in the spectral analysis. These also correspond to solar oscillations that were previously detected in the ${ }^{14} \mathrm{C}$ record (Stuiver and Braziunas, 1989) and were recently shown to modulate SAMS intensity during the late Holocene (Novello et al., 2012). The results presented here demonstrate that such modulation was persistent during most of the Holocene.

The spectral analysis also reveals the presence of several high-frequency $(<50-\mathrm{y})$ oscillations above the $99 \% \chi^{2}$ red-noise level. These are complex to interpret since, in contrast to those discussed above, these are not discrete signals, and might be the result of several processes. For example, a $0.045 \mathrm{y}^{-1}$ signal might correspond to the $22-\mathrm{y}$ solar cycle, also known as Hale-cycle, (Attolini et al., 1990), whilst high-frequency oscillation modes at 0.055 and 0.072 $\mathrm{y}^{-1}$, corresponding to a 14 and 18 years, can be interpreted as the effect from the interdecadal oscillation of ENSO (Mann and Park, 1994), which has been recently described as the bi- 


\section{High-resolution Holocene South American monsoon history recorded by a speleothem from Botuverá Cave, Brazil (Bernal et al).}

387 decadal component of the Pacific Decadal Oscillation (Steinman et al., 2015). Also, a signal at

388

389

390

391

392

393

394

395

396

397

398

399

400

401

402

403

404

405

406

407

408

409

approximately $\sim 0.066 \mathrm{y}^{-1}$ can be attributed to the interdecadal variability of SACZ at 15 years

(Robertson and Mechoso, 2000). Moreover, considering that extratropical moisture represents

a non-negligible fraction of total rainfall in southeastern Brazil (Cruz et al., 2005b), cyclic

modulation by the Southern Annular Mode cannot be ruled out as it has been observed in

southwestern South America (Mundo et al., 2012), and other reconstructions of SAM index

from instrumental data (Visbeck, 2009). From the wavelet analysis, none of these oscillations

appears to be persistent throughout the Holocene, with only sporadic periods of high-

significance, and most are notoriously absent during the last 1500 years. However, the presence

of these oscillations in the spectral analysis and wavelet analysis attests to the numerous

atmospheric and oceanic processes modulating the decadal to centennial variability of SAMS, and highlights the complexity of its interactions.

4.3. The expression of Holocene climate anomalies in southeastern Brazil 4.3.1.The 8.2 event

Besides the investigation of the long-term hydrological changes at Botuverá cave, our high resolution record allows to study the spatial extent of Holocene climatic events that are well preserved in other climate archives: the $8.2 \mathrm{ka}$ event, the Medieval Climate Anomaly (MCA) and the Little Ice Age (LIA). The $8.2 \mathrm{ka}$ event is the largest global climatic anomaly during the Holocene (Alley et al., 1997), with significant climatic consequences throughout most the Northern Hemisphere (Wiersma and Renssen, 2006) where colder and drier conditions prevailed for nearly 200 years (Cheng et al., 2009; Thomas et al., 2007) and a southward migration of the average position of the ITCZ (Broccoli et al., 2006) resulted in a 


\section{High-resolution Holocene South American monsoon history recorded by a speleothem from Botuverá Cave, Brazil (Bernal et al).}

410

411

412

413

414

415

416

417

418

419

420

421

422

423

424

weaker monsoon in the north American tropics (Lachniet et al., 2004). Despite the widespread consequences in the Northern Hemisphere, there are only a few records in the Southern

Hemisphere (Cheng et al., 2009; Ljung et al., 2008; Sallun et al., 2012), mostly due to the lack of well-dated high-resolution records that allow to resolve multidecadal to centennial abrupt events during the Holocene in large areas over the continent.

Figure 7 shows the $\mathrm{Sr} / \mathrm{Ca}$, and $\delta^{18} \mathrm{O}$ records from BTV21a for the $8400-7900$ period, and compares them to those obtained in stalagmites from central Brazil (Cheng et al., 2009), and Dongee Cave, in central China (Wang et al., 2005), as well as the high-resolution composite oxygen isotope record from Greenland (Thomas et al., 2007). The Sr/Ca record indicate that during the $8.2 \mathrm{ka}$ event conditions in southeastern Brazil were wetter for about 170 years, whilst the contemporaneous decrease in the $\delta^{18} \mathrm{O}$ record from the very same speleothem suggests that this was the result from an increased proportion of Amazonian precipitation. This finding is in agreement with other proxy records from southeastern Brazil (Sallun et al., 2012), speleothem records from central Brazil (Cheng et al., 2009; Stríkis et al., 2011) indicating an enhancement of SAMS contemporaneous to the event, and in accordance with previous observation that cooling of the North Atlantic results in a monsoon enhancement in both flanks of the SACZ over Brazil. Furthermore, the proxy data are underpinned by model simulations indicating increased precipitation for the duration of this event as a result from the southward migration of the ITCZ (e.g. Broccoli et al., 2006; Morrill et al., 2013).

The BTV21a Sr/Ca record replicates the "double-plunge" structure previously detected in Greenland ice-cores (Thomas et al., 2007), stalagmites from Brazil, Oman, and China (Cheng et al., 2009), marine cores from the north Atlantic (Ellison et al., 2006), and 


\section{High-resolution Holocene South American monsoon history recorded by a speleothem from Botuverá Cave, Brazil (Bernal et al).}

433

434

435

436

437

438

439

440

441

442

443

444

445

446

447

448

449

450

451

suggested by some "hosing" experiments (LeGrande and Schmidt, 2008), providing further

evidence on the structure of the event: two distinct cooling events with widespread

consequences in both Hemispheres. Wavelet analysis of the annually resolved $\mathrm{Sr} / \mathrm{Ca}$ record for the "double-plunge" period, 8.4-7.9 ky B.P. (Figure 9) shows that the 60-70 year signal, previously interpreted to reflect the influence of the Atlantic Multidecadal Oscillation (AMO) upon SAMS, is significantly weaker for a period of $\sim 40$ year between 8.05 and $8.1 \mathrm{ka}$ B.P, and particularly during the first half of the second "plunge". This suggest that SAMS was decoupled from AMO modulation and implies that either AMO was severely weakened during the event, or the ocean-atmosphere teleconnections behind the "normal" AMO-SAMS coupling were somewhat interrupted. Weakening of AMO probably resulted in the slowing of AMOC during the event (Ellison et al., 2006). However, because AMO modulation of SAMS has been intermittent throughout the Holocene (Figure 8B) it is difficult to associate the weakening of AMO modulation $\sim 8100$ years ago solely to the cooling and freshening of the North Atlantic. Although disruption of AMO has been previously suggested as a consequence of the 8.2 ka event (Hillaire-Marcel et al., 2007), no previous record of such disruption is yet available. Moreover, relevant so-called "hosing" experiments (Broccoli et al., 2006; LeGrande et al., 2006; Morrill et al., 2013) are yet to provide detailed information on the periodic oceanatmosphere interactions (such as AMO) during anomalous paleoceanografic conditions.

4.3.2.The Last Millennium.

Climate during the last thousand years is characterized by two main climatic events: the Medieval Warm Period, also known as Medieval Climate Anomaly (MCA between 950 AD and 1250 AD, and the Little Ice Age, LIA, between 1400 AD and 1850 A.D. (Mann et al., 2009). Whilst the effects of the MCA are more subtle and not easily distinguishable in many 


\section{High-resolution Holocene South American monsoon history recorded by a speleothem from Botuverá Cave, Brazil (Bernal et al).}

456

457

458

459

460

461

462

463

464

465

466

467

468

469

470

471

472

473

474

475

476

477

478

479

records outside Europe, those from the LIA are more evident at lower latitudes and the tropics (Bird et al., 2011). In South America, the climatic consequences of the LIA are spatially complex (Thompson et al., 2013), and it has been suggested that a dry/wet dipole was formed between Southeastern and Northeasthern Brazil (Novello et al., 2012; Vuille et al., 2012).

Figure 8 shows the $\mathrm{Sr} / \mathrm{Ca}$ and $\delta^{18} \mathrm{O}$ records from BTV21a for the 1500 years and compares them against the net solar radiative forcing reconstructed from ${ }^{10} \mathrm{Be}$ abundance in ice cores from Antarctica (Bard et al., 2007), records of rainfall variability of northeastern Brazil from Diva Cave (Novello et al., 2012), and glacier net accumulation from the Quelccaya glacier, eastern Peru (Thompson et al., 2013), an indicator of western Amazonian regional precipitation. The trace element record from BTV21a shows that the increased solar forcing associated with the MCA did not necessarily result in significantly drier conditions in southeastern Brazil. In contrast, the $\mathrm{Sr} / \mathrm{Ca}$ record in BTV21a indicates that the abrupt decrease in solar forcing at $\sim 1350$ A.D is associated with a contemporaneous enhancement of SAMS, and a gradual increase of Amazonian rainfall throughout the LIA, as suggested by the $\sim 0.5 \%$ o shift in the $\delta^{18} \mathrm{O}$ record. This is consistent with the gradual increment in water equivalent accumulation observed in the Quelccaya glacier from eastern Peru (Thompson et al., 2013), but also with speleothem records form Cascayunga Cave that suggests increased convective activity over western Amazonia during the Little Ice Age (Reuter et al., 2009), which resulted in in enhanced subsidence, hence reduced rainfall, over northeastern Brazil (Novello et al., 2012). Consequently, our record provides evidence to support that the dry/wet dipole observed in orbital timescales between Northeastern Brazil and Botuverá (Cruz et al., 2009), previously suggested only by the Cascayunga Cave record (Novello et al., 2012), was also in place during the Little Ice Age. However, further detailed U-Th dating of the stalagmite is needed to provide a more robust chronological to fundament the climate interpretations at the time 


\section{High-resolution Holocene South American monsoon history recorded by a speleothem from Botuverá Cave, Brazil (Bernal et al).}

480

481

482

483

484

485

486

487

488

489

490

491

492

493

interval corresponding to the last millennia in the Botuverá trace-element record, and then to access more definitive answers on the potential climatic consequences of the MCA upon southeastern Brazil and the dynamics of the atmosphere during such relevant event.

\section{Conclusions}

We have shown that the long high-resolution trace element record obtained by LAICPMS from stalagmite BTV21a provides a wealth of information on the hydroclimate dynamics of South America for most of the Holocene. This, however, requires prior examination on the geochemical processes occurring in the karst, upstream the stalagmite, which might be modulating the trace element variability in the stalagmite to identify the elements whose variability is most likely to be controlled by Prior Calcite Precipitation. While these processes appear to be common within the Botuverá karst (Cruz et al., 2007b; Tremaine and Froelich, 2013), they should not be extrapolated to other localities without thorough assessment.

Our Sr/Ca record indicates that SAMS modulation by the Atlantic Multidecadal Oscillation has been intermittent for most of the Holocene, and in conjunction with other marine (Chiessi et al., 2009) and speleothem (Novello et al., 2012; Vuille et al., 2012) records, it is possible to establish that such modulation/coupling has been in place throughout most of the last $18 \mathrm{ka}$. Other factors modulating SAMS intensity, include solar oscillation and ENSO, although the effect from the latter is rather subtle.

Because of the complexity in the interpretation of $\delta^{18} \mathrm{O}$ variability due to the different moisture sources affecting southeastern Brazil, the trace element record from BTV21 a allows 


\section{High-resolution Holocene South American monsoon history recorded by a speleothem from Botuverá Cave, Brazil (Bernal et al).}

502

503

504

505

506

507

508

521 Andes and southeastern Brazil. full confirmation of such conditions.

to couple the information of SAMS intensity with moisture sources, providing a more robust paleoclimate reconstruction. This allows us to detect complex atmospheric dynamics occurring throughout the Holocene and establish that several forcing factors have modulated the strength of SAMS. Our results suggest the placement of a mega-SACZ during cold stadials in the North Atlantic, similar to those occurring under glacial conditions (Stríkis et al., 2015), yet, the low resolution of contemporaneous hydroclimate records from western Amazonia inhibits

The trace element record also provides valuable insights on the climate dynamics during the $8.2 \mathrm{ka}$ event and the Little Ice Age. Our results suggest that the well-known doubleplunge structure of the event detected in marine and continental records can be further expanded to southeastern Brazil. However, detailed analysis of our record suggests that the SAMS/AMO coupling that has been in place for most of the last $18 \mathrm{ka}$, was briefly interrupted for a period of $\sim 100$ years, during the $8.2 \mathrm{ka}$ event. This reveals previously undetected consequences of the abrupt discharge of freshwater into the North Atlantic, and should be verified with further analyses of high-resolution records as well as models of oceanatmosphere interaction to pinpoint the most likely mechanism. Similarly, the effects of the LIA over southeastern Brazil can also be extracted from our record, and in conjunction with other high-resolution hydroclimate records from South America, we are able to confirm the establishment of the dry/wet dipole between northeastern Brazil, western Amazonia, central 
524 6. Acknowldegments

525 The authors wish to thank two anonymous reviewers and Dr. Heather Stoll that provided 526 insightful comments on an earlier version of this manuscript. Funding for this project was

527 provided by UNAM/PAPIIT project IN105713 and CONACyT 78828 to JPB, from

528 NASA/FAPESP through the Dimensions of Biodiversity Program grants 2012/50260-6 and

529 2013/5029-7 and PRIMO cooperative program (CNPq 590172/2011-5) to FWC, Singapore

530 NRFF2011-08 to XF, and NSF grant 1103403 to R.L.E and H.C.

531 


\section{High-resolution Holocene South American monsoon history recorded by a speleothem from}

Botuverá Cave, Brazil (Bernal et al).

532 7. References:

5338.

534 Alley, R.B., Mayewski, P.A., Sowers, T., Stuiver, M., Taylor, K.C., Clark, P.U., 1997. Holocene

535 climatic instability: A prominent, widespread event 8200 yr ago. Geology, 483-486.

536 Apaéstegui, J., Cruz, F.W., Sifeddine, A., Vuille, M., Espinoza, J.C., Guyot, J.L., Khodri, M.,

537 Strikis, N., Santos, R.V., Cheng, H., Edwards, L., Carvalho, E., Santini, W., 2014a.

538 Hydroclimate variability of the northwestern Amazon Basin near the Andean foothills of Peru

539 related to the South American Monsoon System during the last 1600 years. Clim. Past 10,

$540 \quad 1967-1981$.

541 Apaéstegui, J., Cruz, F.W., Sifeddine, A., Vuille, M., Espinoza, J.C., Guyot, J.L., Khodri, M.,

542 Strikis, N., Santos, R.V., Cheng, H., Edwards, L., Carvalho, E., Santini, W., 2014b.

543 Hydroclimate variability of the northwestern Amazon Basin near the Andean foothills of Peru

544 related to the South American Monsoon System during the last 1600 years. Clim. Past 10,

$545 \quad 1967-1981$.

546 Attolini, M.R., Cecchini, S., Galli, M., Nanni, T., 1990. On the persistence of the 22 y solar

547 cycle. Sol Phys 125, 389-398.

548 Auler, A., 2002. Karst areas in Brazil and the potential for major caves-an overview. Boletin de

549 la Sociedad Venezolana de Espeleología 36, 29-35.

550 Baker, P.A., Fritz, S.C., Garland, J., Ekdahl, E., 2005. Holocene hydrologic variation at Lake

551 Titicaca, Bolivia/Peru, and its relationship to North Atlantic climate variation. J. Quat. Sci 20, $552 \quad 655-662$. 


\section{High-resolution Holocene South American monsoon history recorded by a speleothem from Botuverá Cave, Brazil (Bernal et al).}

553 Bard, E., Raisbeck, G.M., Yiou, F., Jouzel, J., 2007. Comment on "Solar activity during the last

554 1000\&\#xa0;yr inferred from radionuclide records” by Muscheler et al. (2007). Quaternary

555 Science Reviews 26, 2301-2304.

556 Basei, M.A.S., Campos Neto, M.C., Castro, N.A., Nutman, A.P., Wemmer, K., Yamamoto,

557 M.T., Hueck, M., Osako, L., Siga, O., Passarelli, C.R., 2011. Tectonic evolution of the Brusque

558 Group, Dom Feliciano belt, Santa Catarina, Southern Brazil. Journal of South American Earth

559 Sciences 32, 324-350.

560 Berger, A., Loutre, M.F., 1991. Insolation values for the climate of the last 10 million years.

561 Quat. Sci. Rev. 10, 297-317.

562 Bird, B.W., Abbott, M.B., Vuille, M., Rodbell, D.T., Stansell, N.D., Rosenmeier, M.F., 2011. A

563 2,300-year-long annually resolved record of the South American summer monsoon from the

564 Peruvian Andes. Proceedings of the National Academy of Sciences 108, 8583-8588.

565 Bond, G., Kromer, B., Beer, J., Muscheler, R., Evans, M.N., Showers, W., Hoffmann, S., Lotti-

566 Bond, R., Hajdas, I., Bonani, G., 2001. Persistent Solar Influence on North Atlantic Climate

567 During the Holocene. Science 294, 2130-2136.

568 Borsato, A., Frisia, S., Fairchild, I.J., Somogyi, A., Susini, J., 2007. Trace element distribution in

569 annual stalagmite laminae mapped by micrometer-resolution X-ray fluorescence: Implications

570 for incorporation of environmentally significant species. Geochimica et Cosmochimica Acta

$571 \quad 71,1494-1512$.

572 Broccoli, A.J., Dahl, K.A., Stouffer, R.J., 2006. Response of the ITCZ to Northern

573 Hemisphere cooling. Geophys. Res. Lett. 33, L01702. 


\section{High-resolution Holocene South American monsoon history recorded by a speleothem from Botuverá Cave, Brazil (Bernal et al).}

574 Bustamante-Rosell, M.G., Cruz, F.W., Siffedine, A., Cheng, H., Apaéstegui, J., Vuille, M., 575 Strikis, N., Moquet, J.S., Novello, V.F., Guyot, J., Edwards, L., Accepted. Holocene Changes

576 in Monsoon Precipitation in the Andes of NE Peru based on $\delta^{18} \mathrm{O}$ speleothem records.

577 Quaternary Science Reviews.

578 Carnaval, A.C., Hickerson, M.J., Haddad, C.F.B., Rodrigues, M.T., Moritz, C., 2009. Stability

579 Predicts Genetic Diversity in the Brazilian Atlantic Forest Hotspot. Science 323, 785-789.

580 Cruz, F., Burns, S.J., Jercinovic, M., Karmann, I., Sharp, W.D., Vuille, M., 2007a. Evidence of

581 rainfall variations in Southern Brazil from trace element ratios $(\mathrm{Mg} / \mathrm{Ca}$ and $\mathrm{Sr} / \mathrm{Ca})$ in a Late

582 Pleistocene stalagmite. GCA 71, 2250-2263.

583 Cruz, F.W., Burns, S.J., Karmann, I., Sharp, W.D., Vuille, M., 2006a. Reconstruction of

584 regional atmospheric circulation features during the late Pleistocene in subtropical Brazil from

585 oxygen isotope composition of speleothems. Earth and Planetary Science Letters 248, 495-507.

586 Cruz, F.W., Burns, S.J., Karmann, I., Sharp, W.D., Vuille, M., Cardoso, A.O., Ferrari, J.A.,

587 Dias, P.L.S., Viana, O., 2005a. Insolation-driven changes in atmospheric circulation over the

588 past 116,000 years in subtropical Brazil. Nature 434, 63-66.

589 Cruz, F.W., Vuille, M., Burns, S.J., Wang, X., Cheng, H., Werner, M., Edwards, R.L., Karmann, 590 I., Auler, A.S., Nguyen, H., 2009. Orbitally driven east-west antiphasing of South-American 591 precipitation. Nature Geosci 2, 210-214.

592 Cruz, J., Francisco W., Burns, S.J., Jercinovic, M., Karmann, I., Sharp, W.D., Vuille, M., 2007b. 593 Evidence of rainfall variations in Southern Brazil from trace element ratios $(\mathrm{Mg} / \mathrm{Ca}$ and $\mathrm{Sr} / \mathrm{Ca})$ 594 in a Late Pleistocene stalagmite. Geochimica et Cosmochimica Acta 71, 2250-2263. 


\section{High-resolution Holocene South American monsoon history recorded by a speleothem from Botuverá Cave, Brazil (Bernal et al).}

595 Cruz, J., Francisco W., Burns, S.J., Karmann, I., Sharp, W.D., Vuille, M., Ferrari, J.A., 2006b. A stalagmite record of changes in atmospheric circulation and soil processes in the Brazilian

597 subtropics during the Late Pleistocene. Quaternary Science Reviews 25, 2749-2761.

598 Cruz, J., Francisco W., Karmann, I., Viana, J., Oduvaldo, Burns, S.J., Ferrari, J.A., Vuille, M., 599 Sial, A.N., Moreira, M.Z., 2005b. Stable isotope study of cave percolation waters in subtropical 600 Brazil: Implications for paleoclimate inferences from speleothems. Chemical Geology 220, $601245-262$.

602 Cheng, H., Fleitmann, D., Edwards, R.L., Wang, X., Cruz, F.W., Auler, A.S., Mangini, A., 603 Wang, Y., Kong, X., Burns, S.J., Matter, A., 2009. Timing and structure of the 8.2 kyr B.P. 604 event inferred from 8180 records of stalagmites from China, Oman, and Brazil. Geology 37, $605 \quad 1007-1010$.

606 Cheng, H., Lawrence Edwards, R., Shen, C.-C., Polyak, V.J., Asmerom, Y., Woodhead, J.,

607 Hellstrom, J., Wang, Y., Kong, X., Spötl, C., Wang, X., Calvin Alexander Jr, E., $2013 a$.

608 Improvements in ${ }^{230} \mathrm{Th}$ dating, ${ }^{230} \mathrm{Th}$ and ${ }^{234} \mathrm{U}$ half-life values, and $\mathrm{U}-\mathrm{Th}$ isotopic 609 measurements by multi-collector inductively coupled plasma mass spectrometry. Earth and 610 Planetary Science Letters 371-372, 82-91.

611 Cheng, H., Sinha, A., Cruz, F.W., Wang, X., Edwards, R.L., d'Horta, F.M., Ribas, C.C., Vuille, 612 M., Stott, L.D., Auler, A.S., 2013b. Climate change patterns in Amazonia and biodiversity. Nat 613 Commun 4, 1411.

614 Chiessi, C.M., Mulitza, S., Pätzold, J., Wefer, G., Marengo, J.A., 2009. Possible impact of the 615 Atlantic Multidecadal Oscillation on the South American summer monsoon. Geophysical 616 Research Letters 36. 


\section{High-resolution Holocene South American monsoon history recorded by a speleothem from Botuverá Cave, Brazil (Bernal et al).}

617 Day, C.C., Henderson, G.M., 2013. Controls on trace-element partitioning in cave-analogue 618 calcite. Geochimica et Cosmochimica Acta 120, 612-627.

619 Ellison, C.R.W., Chapman, M.R., Hall, I.R., 2006. Surface and Deep Ocean Interactions

620 During the Cold Climate Event 8200 Years Ago. Science 312, 1929-1932.

621 Fairchild, I.J., Borsato, A., Tooth, A.F., Frisia, S., Hawkesworth, C.J., Huang, Y., McDermott,

622 F., Spiro, B., 2000. Controls on trace element (Sr-Mg) compositions of carbonate cave waters:

623 implications for speleothem climatic records. Chemical Geology 166, 255-269.

624 Fairchild, I.J., Treble, P.C., 2009. Trace elements in speleothems as recorders of environmental 625 change. Quaternary Science Reviews 28, 449-468.

626 Garreaud, R.D., Vuille, M., Compagnucci, R., Marengo, J., 2009. Present-day South American 627 climate. Palaeogeography, Palaeoclimatology, Palaeoecology 281, 180-195.

628 Grinsted, A., Moore, J.C., Jevrejeva, S., 2004. Application of the cross wavelet transform and 629 wavelet coherence to geophysical time series. Nonlinear Processes in Geophysics 11, 561-566.

630 Hammer, Ø., Harper, D.A.T., Ryan, P.D., 2001. PAST: Paleontological statistics software 631 package for education and data analysis. Palaeontologia Electronica 4.

632 Haug, G.H., Hughen, K.A., Sigman, D.M., Peterson, L.C., Rohl, U., 2001. Southward

633 Migration of the Intertropical Convergence Zone Through the Holocene. Science 293, 1304-

$63413081310.1126 /$ science.1059725. 


\section{High-resolution Holocene South American monsoon history recorded by a speleothem from Botuverá Cave, Brazil (Bernal et al).}

635 Hendy, C.H., 1971. The isotopic geochemistry of speleothems--I. The calculation of the effects

636 of different modes of formation on the isotopic composition of speleothems and their

637 applicability as palaeoclimatic indicators. Geochimica et Cosmochimica Acta 35, 801-824.

638 Hillaire-Marcel, C., de Vernal, A., Piper, D.J.W., 2007. Lake Agassiz Final drainage event in the 639 northwest North Atlantic. Geophysical Research Letters 34, L15601.

640 Kanner, L.C., Burns, S.J., Cheng, H., Edwards, R.L., Vuille, M., 2013. High-resolution

641 variability of the South American summer monsoon over the last seven millennia: insights

642 from a speleothem record from the central Peruvian Andes. Quaternary Science Reviews 75, 1 -

64310.

644 Karmann, I., Cruz Jr, F.W., Viana Jr, O., Burns, S.J., 2007. Climate influence on geochemistry

645 parameters of waters from Santana-Pérolas cave system, Brazil. Chemical Geology 244, 232-

646247.

647 Knudsen, M.F., Seidenkrantz, M.-S., Jacobsen, B.H., Kuijpers, A., 2011. Tracking the Atlantic

648 Multidecadal Oscillation through the last 8,000 years. Nat Commun 2, 178.

649 Lachniet, M.S., 2009. Climatic and environmental controls on speleothem oxygen-isotope

650 values. Quaternary Science Reviews 28, 412-432.

651 Lachniet, M.S., Asmerom, Y., Burns, S.J., Patterson, W.P., Polyak, V.J., Seltzer, G.O., 2004.

652 Tropical response to the $8200 \mathrm{yr}$ BP cold event? Speleothem isotopes indicate a weakened

653 early Holocene monsoon in Costa Rica. Geology 32, 957-960.

654 LeGrande, A.N., Schmidt, G.A., 2008. Ensemble, water isotope-enabled, coupled general

655 circulation modeling insights into the 8.2 ka event. Paleoceanography 23, PA3207. 


\section{High-resolution Holocene South American monsoon history recorded by a speleothem from Botuverá Cave, Brazil (Bernal et al).}

656 LeGrande, A.N., Schmidt, G.A., Shindell, D.T., Field, C.V., Miller, R.L., Koch, D.M., Faluvegi,

657 G., Hoffmann, G., 2006. Consistent simulations of multiple proxy responses to an abrupt

658 climate change event. Proceedings of the National Academy of Sciences of the United States

659 of America 103, 837-842.

660 Liebmann, B., Mechoso, C., 2011. The South American Monsoon System, in: Chang, C.-P., et

661 al. (Eds.), The Global Monsson System: Research and Forecast, 2nd. ed. World Scientific

662 Publication Company, p. 608.

663 Ljung, K., Björck, S., Renssen, H., Hammarlund, D., 2008. South Atlantic island record reveals

664 a South Atlantic response to the $8.2 \mathrm{kyr}$ event. Clim. Past 4, 35-45.

665 Mann, M.E., Park, J., 1994. Global-scale modes of surface temperature variability on

666 interannual to century timescales. Journal of Geophysical Research: Atmospheres 99, 25819-

66725833.

668 Mann, M.E., Zhang, Z., Rutherford, S., Bradley, R.S., Hughes, M.K., Shindell, D., Ammann,

669 C., Faluvegi, G., Ni, F., 2009. Global Signatures and Dynamical Origins of the Little Ice Age 670 and Medieval Climate Anomaly. Science 326, 1256-1260.

671 McDonough, W.F., Sun, S.S., 1995. The Composition of the Earth. Chemical Geology 120, $672 \quad 223-253$.

673 Morrill, C., LeGrande, A.N., Renssen, H., Bakker, P., Otto-Bliesner, B.L., 2013. Model

674 sensitivity to North Atlantic freshwater forcing at $8.2 \mathrm{ka}$. Clim. Past 9, 955-968. 


\section{High-resolution Holocene South American monsoon history recorded by a speleothem from Botuverá Cave, Brazil (Bernal et al).}

675 Mundo, I.A., Masiokas, M.H., Villalba, R., Morales, M.S., Neukom, R., Le Quesne, C., Urrutia, 676 R.B., Lara, A., 2012. Multi-century tree-ring based reconstruction of the Neuquén River

677 streamflow, northern Patagonia, Argentina. Clim. Past 8, 815-829.

678 Novello, V.F., Cruz, F.W., Karmann, I., Burns, S.J., Stríkis, N.M., Vuille, M., Cheng, H., 679 Lawrence Edwards, R., Santos, R.V., Frigo, E., Barreto, E.A.S., 2012. Multidecadal climate 680 variability in Brazil's Nordeste during the last 3000 years based on speleothem isotope records. 681 Geophysical Research Letters 39, L23706.

682

683

684 685 686
Polyak, V.J., Asmerom, Y., Burns, S.J., Lachniet, M.S., 2012. Climatic backdrop to the terminal Pleistocene extinction of North American mammals. Geology 40, 1023-1026.

Razik, S., Chiessi, C.M., Romero, O.E., von Dobeneck, T., 2013. Interaction of the South American Monsoon System and the Southern Westerly Wind Belt during the last 14\&\#xa0;kyr. Palaeogeography, Palaeoclimatology, Palaeoecology 374, 28-40.

Reimer, P.J., Baillie, M.G.L., Bard, E., Bayliss, A., Beck, J.W., Bertrand, C.J.H., Blackwell, P.G., Buck, C.E., Burr, G.S., Cutler, K.B., Damon, P.E., Edwards, R.L., Fairbanks, R.G., Friedrich, M., Guilderson, T.P., Hogg, A.G., Hughen, K.A., Kromer, B., McCormac, G., Manning, S., Ramsey, C.B., Reimer, R.W., Remmele, S., Southon, J.R., Stuiver, M., et al., 2004. IntCal04 terrestrial radiocarbon age calibration, 0-26 cal kyr BP. Radiocarbon 46, 1029-1058.

Reuter, J., Stott, L., Khider, D., Sinha, A., Cheng, H., Edwards, R.L., 2009. A new perspective on the hydroclimate variability in northern South America during the Little Ice Age.

Geophysical Research Letters 36, L21706. 


\section{High-resolution Holocene South American monsoon history recorded by a speleothem from Botuverá Cave, Brazil (Bernal et al).}

695 Robertson, A.W., Mechoso, C.R., 2000. Interannual and Interdecadal Variability of the South 696 Atlantic Convergence Zone. Monthly Weather Review 128, 2947-2957.

697 Sallun, A.E.M., Sallun Filho, W., Suguio, K., Babinski, M., Gioia, S.M.C.L., Harlow, B.A.,

698 Duleba, W., De Oliveira, P.E., Garcia, M.J., Weber, C.Z., Christofoletti, S.R., Santos, C.d.S.,

699 Medeiros, V.B.d., Silva, J.B., Santiago-Hussein, M.C., Fernandes, R.S., 2012. Geochemical

700 evidence of the $8.2 \mathrm{ka}$ event and other Holocene environmental changes recorded in

701 paleolagoon sediments, southeastern Brazil. Quaternary Research 77, 31-43.

702 Schlesinger, M.E., Ramankutty, N., 1994. An oscillation in the global climate system of period

$703 \quad 65-70$ years. Nature 367, 723-726.

704 Schulz, M., Mudelsee, M., 2002. REDFIT: estimating red-noise spectra directly from unevenly

705 spaced paleoclimatic time series. Computers \& Geosciences 28, 421-426.

706 Shen, C.-C., Lawrence Edwards, R., Cheng, H., Dorale, J.A., Thomas, R.B., Bradley Moran, S.,

707 Weinstein, S.E., Edmonds, H.N., 2002. Uranium and thorium isotopic and concentration

708 measurements by magnetic sector inductively coupled plasma mass spectrometry. Chemical

709 Geology 185, 165-178.

710 Sinclair, D.J., 2011. Two mathematical models of $\mathrm{Mg}$ and Sr partitioning into solution during

711 incongruent calcite dissolution: Implications for dripwater and speleothem studies. Chemical

712 Geology 283, 119-133.

713 Smith, C.L., Fairchild, I.J., Spötl, C., Frisia, S., Borsato, A., Moreton, S.G., Wynn, P.M., 2009.

714 Chronology building using objective identification of annual signals in trace element profiles of 715 stalagmites. Quaternary Geochronology 4, 11-21. 


\section{High-resolution Holocene South American monsoon history recorded by a speleothem from Botuverá Cave, Brazil (Bernal et al).}

716

717

718

719

720

721 Stríkis, N.M., Cruz, F.W., Cheng, H., Karmann, I., Edwards, R.L., Vuille, M., Wang, X., de

722 Paula, M.S., Novello, V.F., Auler, A.S., 2011. Abrupt variations in South American monsoon

723

724 Geology 39, 1075-1078.

725 Stríkis, N.M., Chiessi, C.M., Cruz, F.W., Vuille, M., Cheng, H., de Souza Barreto, E.A.,

726 Mollenhauer, G., Kasten, S., Karmann, I., Edwards, R.L., Bernal, J.P., Sales, H.d.R., 2015.

727 Timing and structure of Mega-SACZ events during Heinrich Stadial 1. Geophysical Research

728 Letters, n/a-n/a.

729 Stuiver, M., Braziunas, T.F., 1989. Atmospheric ${ }^{14} \mathrm{C}$ and century-scale solar oscillations. Nature $730338,405-408$.

731 Thomas, E.R., Wolff, E.W., Mulvaney, R., Steffensen, J.P., Johnsen, S.J., Arrowsmith, C.,

732 White, J.W.C., Vaughn, B., Popp, T., 2007. The $8.2 \mathrm{ka}$ event from Greenland ice cores.

733 Quaternary Science Reviews 26, 70-81.

734 Thompson, L.G., Mosley-Thompson, E., Davis, M.E., Zagorodnov, V.S., Howat, I.M., 735 Mikhalenko, V.N., Lin, P.-N., 2013. Annually Resolved Ice Core Records of Tropical Climate 736 Variability over the Past $\sim 1800$ Years. Science 340, 945-950. 


\section{High-resolution Holocene South American monsoon history recorded by a speleothem from Botuverá Cave, Brazil (Bernal et al).}

737 Treble, P., Shelley, J.M.G., Chappell, J., 2003. Comparison of high resolution sub-annual

738

739

740

741

742

743

744

745

746

747

748

749

750

751

752 Vuille, M., Burns, S.J., Taylor, B.L., Cruz, F.W., Bird, B.W., Abbott, M.B., Kanner, L.C.,

753 Cheng, H., Novello, V.F., 2012. A review of the South American monsoon history as recorded

754 in stable isotopic proxies over the past two millennia. Clim. Past 8, 1309-1321.

755 Wang, X., Auler, A.S., Edwards, R.L., Cheng, H., Ito, E., Solheid, M., 2006. Interhemispheric

756 anti-phasing of rainfall during the last glacial period. Quaternary Science Reviews 25, 3391-

7573403. 

Botuverá Cave, Brazil (Bernal et al).

758 Wang, X., Auler, A.S., Edwards, R.L., Cheng, H., Ito, E., Wang, Y., Kong, X., Solheid, M.,

759 2007. Millennial-scale precipitation changes in southern Brazil over the past 90,000 years.

760 Geophysical Research Letters 34, L23701.

761 Wang, Y., Cheng, H., Edwards, R.L., He, Y., Kong, X., An, Z., Wu, J., Kelly, M.J., Dykoski,

762 C.A., Li, X., 2005. The Holocene Asian Monsoon: Links to Solar Changes and North Atlantic

763 Climate. Science 308, 854-857.

764 Wiersma, A.P., Renssen, H., 2006. Model-data comparison for the 8.2 ka BP event:

765 confirmation of a forcing mechanism by catastrophic drainage of Laurentide Lakes.

766 Quaternary Science Reviews 25, 63-88.

767

768 


\section{High-resolution Holocene South American monsoon history recorded by a speleothem from Botuverá Cave, Brazil (Bernal et al).}

Figure captions

Figure 1. Summer and winter 1950-2010 average upward longwave radiation flux as an indicator of convective activity over South America (data from NCEP Reanalysis 2 data provided by the NOAA/OAR/ESRL PSD, Boulder, Colorado, USA, from their Web site at http://www.esrl.noaa.gov/psd/cgi-bin/data/composites/printpage.pl) and highlighting the mean position of the Intertropical Convergence Zone (ITCZ) and the South American Convergence Zone (SACZ). Numbers indicate location of different sites discussed in the text. 1) Botuverá Cave, 2) Lapa Grande cave (Stríkis et al., 2011), 3) Padre cave (Cheng et al., 2009), 4) Diva de Maura cave (Novello et al., 2012), 5) Cariaco basin (Haug et al., 2001), 6) Palestina Cave (Apaéstegui et al., 2014b) 7) Huagapo cave (Kanner et al., 2013), 8) Quelccaya glacier (Thompson et al., 2013). White arrow for the summer indicates the general simplified trajectory of the Low Level Jet (LLJ) during summer. Black arrows indicate the simplified trajectory of extratropical moisture. The $\delta^{18} \mathrm{O}$ values represent the modern amount weighted average isotopic composition of rainfall at the nearest GNIP station in Porto Alegre, Brazil (Cruz et al., 2005b)

Figure $2 \mathrm{~A}):{ }^{230} \mathrm{Th}$-ages v.s. distance from stalagmite tip to build age-model used in this work. B) growth-rate variability for stalagmite BTV21a, showing that the sample grew $\sim 20-30 \mu \mathrm{m}$ per year except for the last millennia when growth rate decreased significantly to $10-15 \mu \mathrm{m}$ per year. C) Initial $\delta^{234} \mathrm{U}$ v.s. age, showing a gradual decrease from the early to the late Holocene.

Figure 3. Comparison of hydroclimate proxies from stalagmite BTV21a: from top to bottom: calcite $\delta^{18} \mathrm{O}$ (VPDB), Sr/Ca, Ba/Ca and $\mathrm{Mg} / \mathrm{Ca}$. Markers at top shows dated parts of the stalagmite. 


\section{High-resolution Holocene South American monsoon history recorded by a speleothem from Botuverá Cave, Brazil (Bernal et al).}

Figure 4. A) Covariation of $\ln (\mathrm{Mg} / \mathrm{Ca})$ vs $\ln (\mathrm{Sr} / \mathrm{Ca})$ showing that the covariance between the molar ratios is mostly affected by PCP, but other processes might be also playing a significant role in the observed variability, in particular $\mathrm{Mg} / \mathrm{Ca}$. Black line shows the corresponding linear regression, red line shows the expected slope (solid $=0.88)$ and their proposed limits (dashed lines) from thermodynamic and kinetic calculation if only PCP is modulating the observed variability (Sinclair, 2011) B) Covariation of the $\ln (\mathrm{Sr} / \mathrm{Ca})$ vs $\ln (\mathrm{Ba} / \mathrm{Ca}) \mathrm{mol} / \mathrm{mol}$; black and red lines are similar as in A, theoretical lines calculated following the systematics of Sinclair (2011), and the distribution coefficients from Day and Henderson (2013) at $25^{\circ} \mathrm{C}$. Similarity in trends between the theoretical and observed covariation suggests that the hydrological processes affecting $\mathrm{Mg} / \mathrm{Ca}$ variability did not affect significantly the $\mathrm{Sr} / \mathrm{Ca}$ and $\mathrm{Ba} / \mathrm{Ca}$ records, and that the observed variability in these is modulated mostly by PCP. C) Covariance of Sr/Ca with calcite $\delta^{18} \mathrm{O}$, symbol color represents the corresponding $\mathrm{Ba} / \mathrm{Ca}$ for each point and shows that $\mathrm{Ba} / \mathrm{Ca}$ is also correlated with calcite $\delta^{8} \mathrm{O}$ with lower $\mathrm{Ba} / \mathrm{Ca}$ values (red) clustered at the lower left corner, while high $\mathrm{Ba} / \mathrm{Ca}$ values (dark blue) clustered at the upper right (reader is referred to the electronic version of the manuscript)

Figure 5. A) Comparison of the $\mathrm{Sr} / \mathrm{Ca}$ and $\delta^{18} \mathrm{O}$ records from BTV21 with the $\delta^{18} \mathrm{O}$ record from Lapa-Grande cave (Stríkis et al., 2011) and Huacapo cave (Kanner et al., 2013) showing a correlation between the wet excursions in central eastern Brazil and Amazonia with wet periods in south eastern Brazil. Markers on top show dated points for BTV21a (green) LG (black) and Huacapo (blue). Light blue line is February insolation at $30^{\circ} \mathrm{S}$ (Berger and Loutre, 1991), note the inverse scale. B) Comparison of LG $\delta^{18} \mathrm{O}$ and BTV21a Sr/Ca vs. INTCAL04 (Reimer et-al, 2004) $\Delta^{14} \mathrm{C}$ for the 7-8 ky (B.P.) period. C) correlation(anticorrelation) between BTV21a (LG-11) and $\Delta^{14} \mathrm{C}$ from INTCAL04.

Figure 6 A) Spectral analysis of the Sr/Ca BTV21a record and the $\chi^{2} 99 \%$ red-noise level as calculated by Red-Fit (Schulz and Mudelsee, 2002), color bands identify the most prominent oscillations: solar (Grey), Atlantic Multidecadal Oscillation (cyan). Inset shows detail of the low-frequency section of the power-spectra. B) Wavelet power spectrum using a Morlet wave function for the Sr/Ca record; shaded areas denote the zone cone of confidence. Dashed box delimits AMO period. Continuous horizontal lines denote solar oscillations.

Figure 7. Comparison of the $\delta^{18} \mathrm{O}$ and $\mathrm{Sr} / \mathrm{Ca}$ from BTV21a records for the period between 7.9 and $8.4 \mathrm{ka}$ with the $\delta^{18} \mathrm{O}$ records from Padre caves, central Brazil, and Dongee Cave, China, (Cheng et al., 2009) and Greenland Ice Core $\delta^{18} \mathrm{O}$ composite (Thomas et al 2007), and the wavelet power spectrum of the $\mathrm{Sr} / \mathrm{Ca}$ record using Morlet wave function. Shaded areas indicate the cone of confidence and the black lines de $95 \%$ confidence intervals. 

Botuverá Cave, Brazil (Bernal et al).

Figure 8. Comparison of the $\delta^{18} \mathrm{O}$ and $\mathrm{Sr} / \mathrm{Ca}$ from BTV21a records for the last millennium and compared with the Net Radiative Forcing reconstructed from variability in ${ }^{10} \mathrm{Be}$ from the Antarctica (Bard et al., 2007), and $\delta^{18} \mathrm{O}$ records from Diva Cave, northeastern Brazil (Novello et al., 2012) and the Net Balance Accumulation (in meters per year water equivalent), an indicator or regional precipitation estimated for the Quelccaya Ice core (Thompson et al., 2013). Note the reversed axis for the Net Accumulation in the Quelccaya Ice core. 

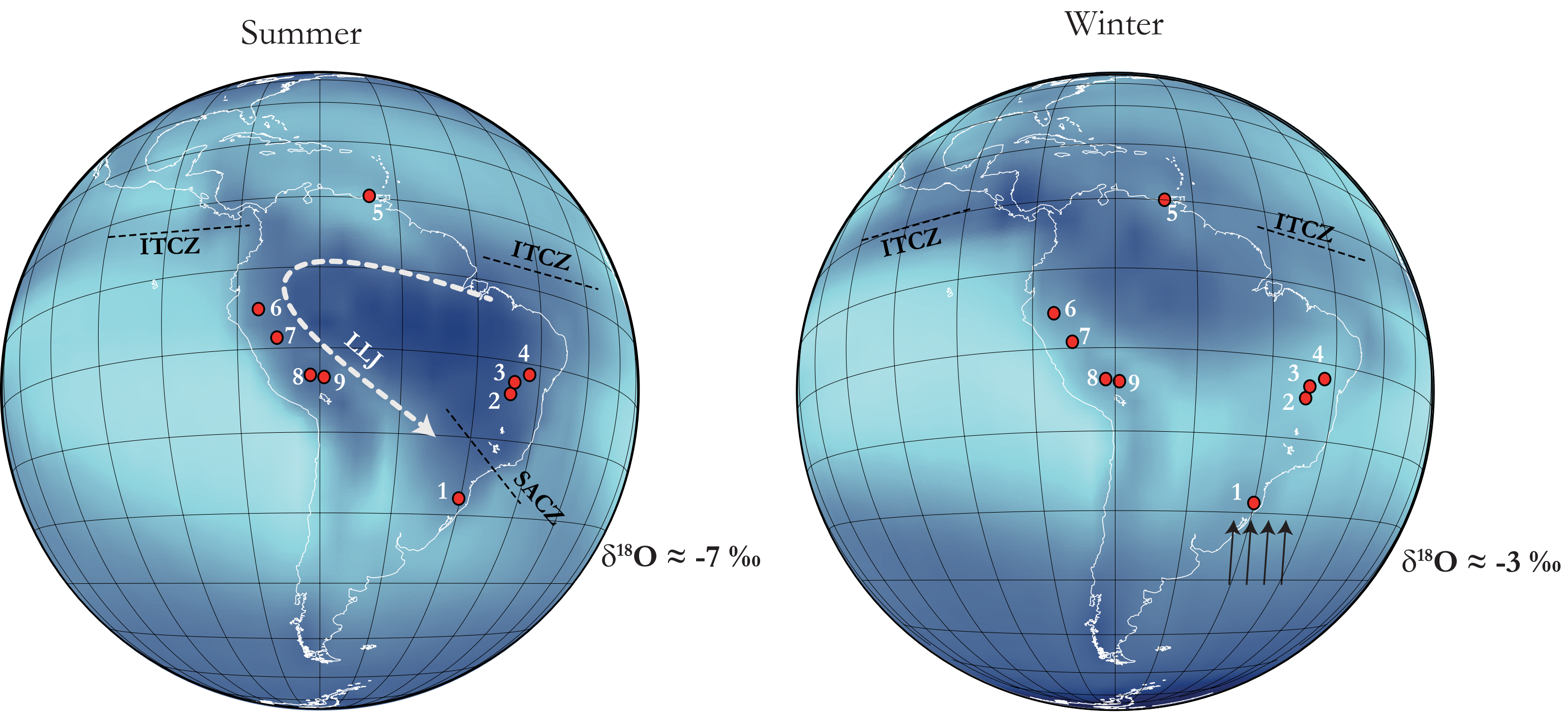

Upward Longwave Radiation Flux (W/m²)

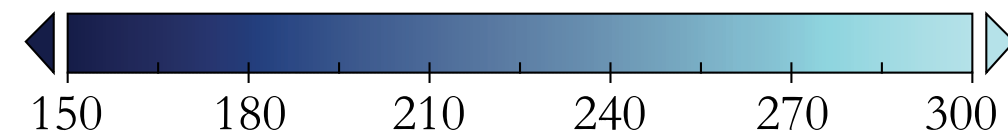

Figure 1

Bernal, et-al. 





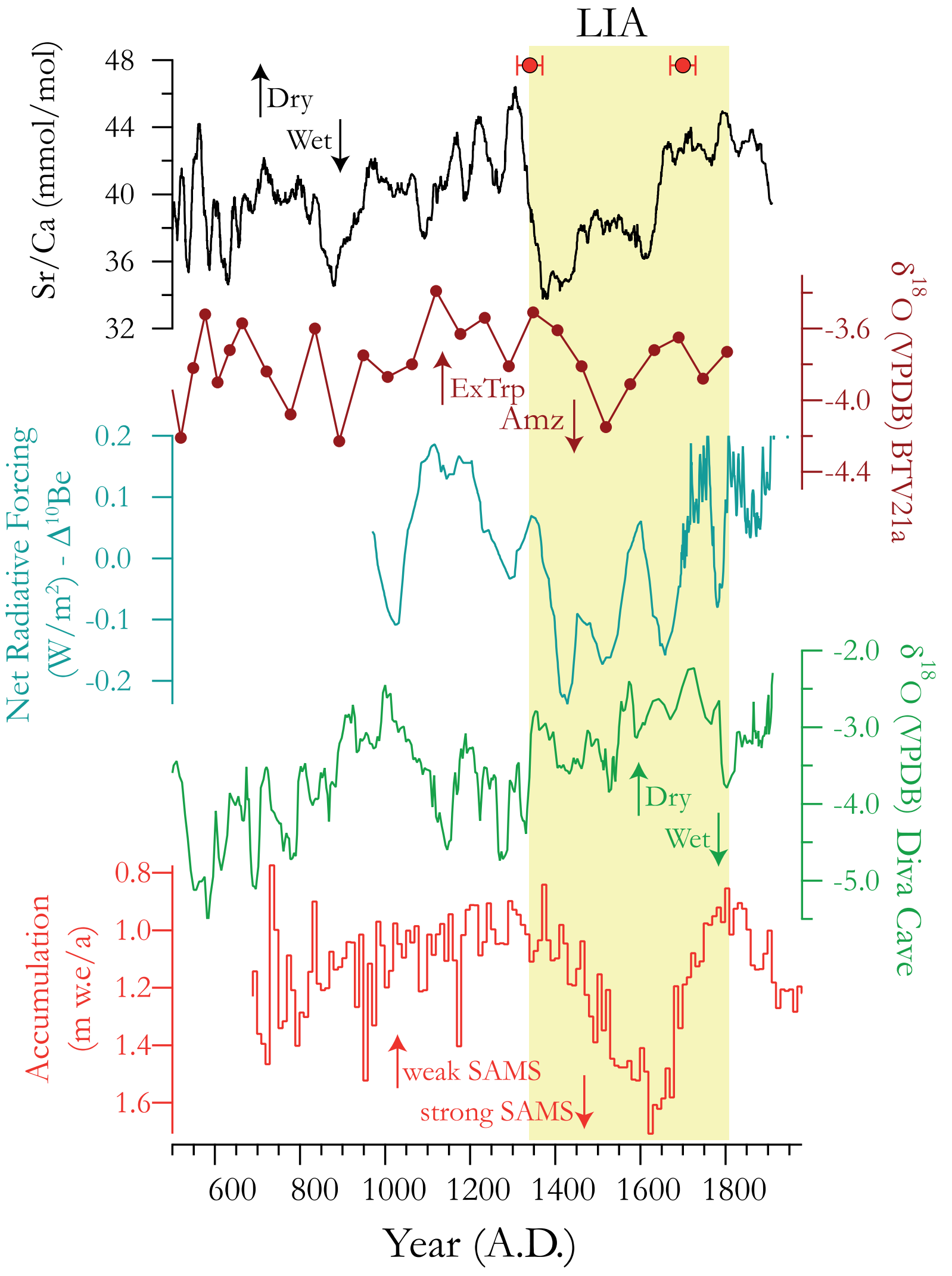

Figure 8 Bernal, et-al. 